\title{
The use of rhizobium and mycorrhizae in soil containing rhizobiophage to improve
}

\section{growth and nodulation of cowpea}

\author{
Yasmine Allam ${ }^{1 *} \odot$, Gehan Amin ${ }^{1} \odot$, Gamal Abdel Fattah ${ }^{2} \odot$, Abeer Hashem ${ }^{3 \oplus}$, Diffuza Egamberdieva ${ }^{4} \odot$, Elsayed Fathi Abd_Allah ${ }^{5}$, \\ Gamal El-Didamony 1 (이
}

\author{
1Zagazig University/Faculty of Science - Dept. of Botany and \\ Microbiology, P.O. Box 44519 - Zagazig - Egypt. \\ ${ }^{2}$ Mansoura University/Faculty of Science - Dept. of Botany, \\ P.O. Box 35516 - 11432 - Mansoura - Egypt. \\ 3King Saud University/College of Science - Dept. of Botany \\ and Microbiology, P.O. Box 2460 - Riyadh - 11451 - Saudi \\ Arabia. \\ ${ }^{4}$ National University of Uzbekistan/Faculty of Biology, \\ 100174 - Tashkent, Uzbekistan. \\ ${ }^{5}$ King Saud University/College of Food and Agricultural \\ Sciences - Plant Production Dept., P.0. Box 2460 - 11451 \\ - Riyadh - Saudi Arabia. \\ *Corresponding author <yasmineallam332003@gmail.com>
}

Edited by: Fernando Dini Andreote

Received April 28, 2021

Accepted June 30, 2021
ABSTRACT: The interaction between leguminous plants and rhizosphere microorganisms is essential because it can either enhance or inhibit the beneficial effects of individual species. Phages are one of the biotic factors with a negative impact on the beneficial bacteria in soil rhizosphere. In the current study, phage showed lytic activity against Bradyrhizobium sp. Vigna (tal16) with an icosahedral head at a $43.44 \mathrm{~nm}$ diameter and a long non-contractile tail, measuring $99.85 \mathrm{~nm}$. This phage belongs to the Siphoviridae family, found in the Met El-Ez area of Dakalia Governorate in Egypt. The results revealed that the presence of phage in soil affected nodulation and growth parameters. Mycorrhizal inoculation aggravated the negative effects of this phage. Cowpea grown in soil containing phage VB_BrV_SD4 showed a reduction in the nodule number, nitrogenase activity, and total $\mathrm{N}$ of $40-50 \%$; however, mycorrhizal inoculation augmented this negative effect with a reduction percentage to 20-28\%. Mycorrhizal inoculation also improved total chlorophyll, carotenoids, legume amount, and the seed protein content.

Keywords: symbiosis, interaction, bacteriophage, agricultural microorganisms, nitrogen fixation

\section{Introduction}

Cowpea [Vigna unguiculata (L.) Walp.] is an important legume crop whose yield depends on the legumespecific strain of rhizobium that fixes $\mathrm{N}$ into ammonia, a crucial component in chlorophyll and protein synthesis (Singh et al., 2007). The high growth rate of legume plants depends on $\mathrm{N}$ fixation by rhizobium. Nitrogen builds amino acids, purines, pyrimidines, producing proteins and nucleic acids and building enzymes (Muleta, 2017).

A vascular arbuscular mycorrhiza (VAM) ("fungus - root") is an endophytic, biotrophic, mutualistic symbiosis in which arbuscular mycorrhiza (AM) fungi are coenocytic, with hundreds of nuclei in their hyphae and spores (Zhu and Yao, 2004). Arbuscular mycorrhizal fungi (AMF) can absorb immobile nutrients in plants, particularly phosphorus (Abdel-Fattah et al., 2014; van der Heijden et al., 2015). AMF reduces the use of chemical fertilizer by up to a half (Rai, 2006).

The symbiotic process between legumes and bradyrhizobium and VAM promotes plant growth and nutrient absorption, while inhibiting pathogen activity (Artursson et al., 2006). Mycorrhiza absorbs phosphorus $(\mathrm{P})$ and uses it in energy metabolism, triggering $\mathrm{N}$ fixation by rhizobium (Whiting and Dilworth, 1974), nodule formation, and plant growth (Muleta, 2017). This dual colonization increases the growth and mycorrhizal inoculation rate as well as nodulation parameters, $\mathrm{N}_{2}$ fixation, and $\mathrm{N}_{2}$ and the $\mathrm{P}$ content in pea compared with nodulated legume plants only (Stancheva et al., 2006; Mugabo and Bhople, 2015).

Rhizobiophages are bacteriophages that infect rhizobium. A rhizosphere has a large number of bacteria around the root system thus a suitable place for phages (Swanson et al., 2009). This rhizobiophage for Bradyrhizobium japonicum decreases the nodulation process, foliar $\mathrm{N}$, nitrogenase activity, and shoot weight (Ahmad and Morgan, 1994; Liu et al., 2019).

This study investigated how AMF could help Vigna unguiculata reduce the negative effects caused by rhizobiophage on nodulation and growth parameters.

\section{Materials and Methods}

\section{Microorganisms}

The Egyptian strain Bradyrhizobium sp. Vigna (tal16) was obtained as a ready-pure isolate and serologically characterized by Agriculture Research Center in Kafr El-Sheikh governorate, Egypt.

Phage VB_BrV_SD4 was isolated from Vigna unguiculata rhizosphere soils in the Met El-Ez region, Dakalia Governorate, Egypt. The single plaques of this phage were isolated according to procedures used by Dhar et al. (1979).

The vascular arbuscular mycorrhizae which included a mixture of Funneliformis mosseae (Walker \& 
Schubler Comb nov.) and Rhizoglomus clarum (Nicolson \& Schenck) Sieverd., G.A. Silva \& Oehl comb. Nov.) were obtained as a ready pure isolate from Mansoura, Dakhalia, Egypt.

\section{Preparation of AMF inoculum}

The inoculum of AMF species, including Funneliformis mosseae and Rhizoglomus clarum, were isolated from field soil cultivated by cowpea of Dakhalia Governorate, Egypt, using the wet sieving and decanting technique (Gerdemann and Nicolson, 1963) and identified by the author. The AMF spores identified were left to multiply for five months on onion (Allium cepa) plants. A mixture of plant roots and sand soil that contained the spores was used as the mycorrhizal inoculum.

\section{Transmission electron microscope (TEM)}

The morphological characteristics of phages were determined by TEM supported by the carbon-coated formvar film. The phages were negatively stained with $2 \%\left(\mathrm{w} \mathrm{v}^{-1}\right)$ of the aqueous phosphate tungsten acid, $\mathrm{pH}$ 7.2 for $1 \mathrm{~min}$. Then, air-dried for $1 \mathrm{~h}$ at room temperature in the Electron Microscope Unit, Mansoura, Dakhalia, Egypt according to procedures used by Ackermann and Prangishvili (2012).

\section{Pot experiments}

The pot experiment allows investigating combinations between mycorrhizae, Bradyrhizobium, and rhizobiophage in the growth and nodulation process. The experiment was conducted in plastic pots $(25 \times$ $30 \mathrm{~cm}$ : length $\times$ diameter) in controlled environmental greenhouse conditions $\left(30{ }^{\circ} \mathrm{C}\right.$ day/25 ${ }^{\circ} \mathrm{C}$ night temperatures, $70 \%$ relative humidity, $16 / 8 \mathrm{~h}$ light/ dark period cycle with a photosynthetic photon flux density of 500-700 mole $\mathrm{m}^{-2} \mathrm{~s}^{-1}$ ) at Mansoura, Dakhalia

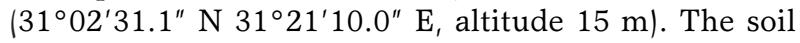
used in the experiment was composed of clay: silt: sand $\left(4: 2: 1 \mathrm{v} \mathrm{v}^{-1}\right)$ with $8.1 \mathrm{pH}, 3.45 \mathrm{EC}, 1.24 \% \mathrm{OM}$, $65 \mathrm{mg} \mathrm{kg}{ }^{-1} \mathrm{~N}, 10.5 \mathrm{mg} \mathrm{kg}^{-1} \mathrm{P}, 124 \mathrm{mg} \mathrm{kg}^{-1} \mathrm{~K}$. Each pot contained $6 \mathrm{~kg}$ of soil. Total $\mathrm{P}$ was extracted by nitric perchloric acid digestion and measured using the Vanado molybdo phosphoric acid colorimetric method (Jackson, 1973).

Total potassium $(\mathrm{K})$ was assayed using a flame spectrophotometer. Total $\mathrm{N}$ was determined by the Kjeldahl method (Nelson and Sommers, 1973).

The research experiment included six treatments: (1) control, (2) VAM inoculation, (3) bradyrhizobium inoculation, (4) bradyrhizobium and VAM inoculation, (5) bradyrhizobium and rhizobiophage inoculation, and (6) bradyrhizobium, VAM and rhizobiophage inoculation. Every pot contained five cowpea seeds, which were thinned to thee after seven days of sowing. The trial was designed with three replications.

\section{Bradyrhizobium cultivation}

The germinated seedlings in sterile agar media were immersed for $1 \mathrm{~h}$ in a 3-day-old bradyrhizobium culture in yeast mannitol broth media containing

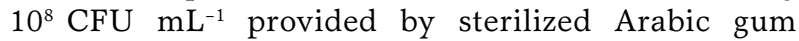
solution (Heffner et al., 2009). Before sowing, a thin layer of mycorrhizal inoculum (15 gm mixed inoculums) was placed on the seeds at a depth of 4 $\mathrm{cm}$. Non-mycorrhizal pots were given equal sterilized mycorrhizal inoculum to provide the same nutrient without mycorrhizal spores.

\section{Phage VB_BrV_SD4 inoculation}

In the phage treatment, phage VB_BrV_SD4 was mixed with the soil by mix $1.0 \times 10^{7} \mathrm{PGU}^{-1}$ soil (Hashem and Angle, 1990).

\section{Fresh and Dry Weights}

Fresh and dry weights were determined in cowpea shoots after $45 \mathrm{~d}$ of cultivating plants and the roots were carefully washed with tap water to minimize soil particles. Upon reaching a constant weight, the shoot and root samples reached were dried in an oven at $70^{\circ} \mathrm{C}$ for $72 \mathrm{~h}$. Dried samples were weighed on a scale of \pm $0.001 \mathrm{~g}$ (Huang et al., 2017).

\section{Chlorophylls a \& b}

The photosynthetic pigments, such as chlorophyll a, chlorophyll b, carotenoids, and total chlorophyll, were determined by Metzner et al. (1965) and Horváth et al. (1972).

Leaf weight Chl.a $=\left(10.3 \mathrm{~A}_{663}-0.918 \mathrm{~A}_{644}\right)$

Weight Chl.b $=\left(19.7 \mathrm{~A}_{644}-3.870 \mathrm{~A}_{663}\right)$

Carotenoids $=4.2 \mathrm{~A}_{452.5}-(0.0264$ Chl. $\mathrm{a}+0.426 \mathrm{Chl} . \mathrm{b})$.

\section{Protein Content}

The modified Lowry protein was measured as previously described by Hartee (1972).

\section{$N, P$, and $K$ contents}

The contents of N, P and $\mathrm{K}$ were determined the Kafr Elsheikh Governorate, according to procedures used by Chapman (1961).

\section{Levels of mycorrhizal colonization}

The mycorrhizal inoculation levels were determined in cowpea root tissues after clearing and staining in $0.05 \%$ trypan blue in lactophenol (Phillips and Hayman, 1970). 


\section{Nitrogenase enzyme activity}

The nitrogenase enzyme activity of root nodules was determined by acetylene reduction activity according to procedures used by Hardy et al. (1973).

\section{Statistical analyses}

The results of the present experiment are expressed as the mean of three replicates \pm standard error. All findings were analyzed by SPSS software (version 15) (Levesque, 2007). Data were statistically analyzed using a one-way analysis of variance (ANOVA) with XLSTAT 2018 statistical software and the means were compared using the Newman-Keuls test $(p>5 \%)$.

\section{Results}

\section{Transmission electron microscope (TEM (of isolated phage (VB_BrV_SD4)}

TEM showed the morphology of the selected phages. Phage VB_BrV_SD4 was isolated against Bradyrhizobium sp. Vigna (tal169) in Figure 1. It showed only a head and tail and belonged to the family phages (Siphoviridae). The head shape was icosahedral in shape, measuring $43.44 \mathrm{~nm}$. The long non-contractile tail was measured at $99.85 \mathrm{~nm}$.

\section{Nodule numbers, Nitrogenase enzyme activity, and dry weight}

Cowpea plants (Vigna unguiculata) grown in soil containing phage VB_BrV_SD4 inoculated with Bradyrhizobium sp. Vigna (tal16) showed a significant reduction in nodulation where the nodule number reduced in the presence of phages from 62.67 to 35.33 (n per plant), nitrogenase from 3.70 to $2.20\left(\mu \mathrm{mol} \mathrm{C}_{2} \mathrm{H}_{4}\right.$ per plant $\left.\mathrm{h}^{-1}\right)$, and dry weight of nodules from 0.07 to 0.034 (g per plant). However, mycorrhizal inoculation reduced these parameters from $44,40.5$, and $41.5 \%$ to 20,28 , and $12 \%$, respectively (Table 1 ).

\section{Mycorrhization frequency and intensity evaluation}

Table 1 shows that the frequency and intensity of VAM of the cowpea plant. Although phage VB_BrV_ SD4 significantly reduced mycorrhizal colonization levels, bradyrhizobium significantly increased them. Figure 2 shows the difference between mycorrhized and non-mycorrhized cowpea plantstained roots.

\section{Pigment content}

Data in Table 2 show that the presence of phage VB_ BrV_SD4 affected the total chlorophyll content and carotenoids, reducing the amount of total chlorophyll in the cowpea plant inoculated with bradyrhizobium from 19.55 to 17.88 and carotenoids from 8.68 to 7.08. However, mycorrhizal inoculation reduced total chlorophyll and carotenoids from 8.6 and $10 \%$ to 6.4 and $4.8 \%$, respectively.

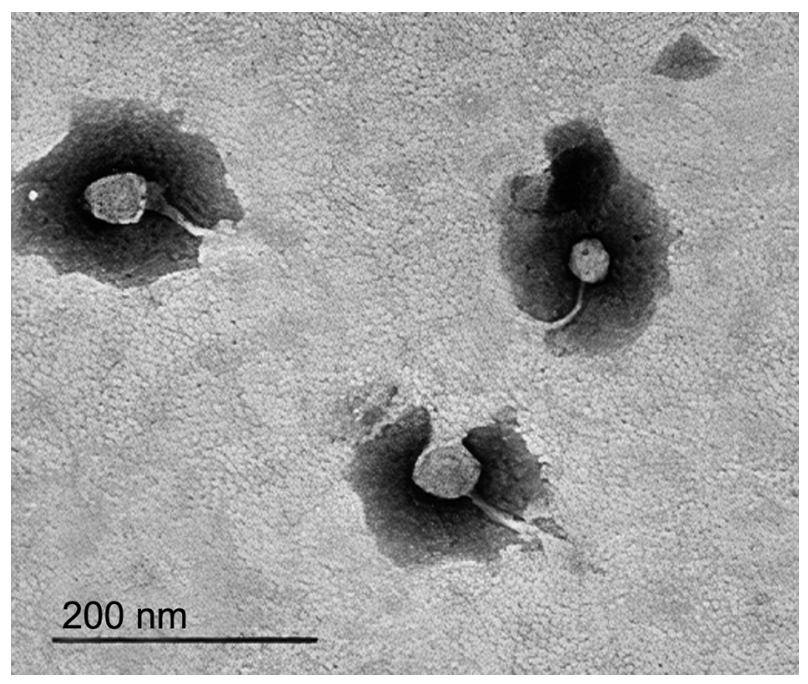

Figure 1 - Electron micrograph of rhizobiophage specific against Bradyrhizobium sp. Vigna (tal169).

Table 1 - Effect of bradyrhizobial, mycorrhizal, rhizobiophage inoculation in nodulation process, nitrogenase, and mycorrhizal inoculation in flowering stage.

\begin{tabular}{|c|c|c|c|c|c|c|}
\hline \multirow{2}{*}{ Treatment } & \multirow{2}{*}{ Number of nodules } & \multirow{2}{*}{ Dry weight of nodules } & \multirow{2}{*}{ Nitrogenase } & \multicolumn{3}{|c|}{ Mycorrhizal inoculation level } \\
\hline & & & & $\mathrm{F} \%$ & $\mathrm{M} \%$ & $A \%$ \\
\hline & n per plant & g per plant & $\mu \mathrm{mol} \mathrm{C}_{2} \mathrm{H}_{4}$ per plant $\mathrm{h}^{-1}$ & & & \\
\hline Control & $9.67 \pm 1.53^{e}$ & $0.01 \pm 0.00^{e}$ & $0.00 \pm 0.00^{d}$ & 0 & 0 & 0 \\
\hline M & $12.00 \pm 2.00^{e}$ & $0.01 \pm 0.00^{\mathrm{e}}$ & $0.00 \pm 0.00^{d}$ & 15 & 27 & 63 \\
\hline $\mathrm{R}$ & $62.67 \pm 8.74^{c}$ & $0.07 \pm 0.01^{c}$ & $3.70 \pm 0.47^{b}$ & 0 & 0 & 0 \\
\hline$R+M$ & $118.00 \pm 6.56^{a}$ & $0.125 \pm 0.01^{\mathrm{a}}$ & $5.30 \pm 0.47^{a}$ & 17 & 31 & 100 \\
\hline $\mathrm{R}+\mathrm{Ph}$ & $35.33 \pm 4.51^{d}$ & $0.034 \pm 0.01^{d}$ & $2.20 \pm 0.31^{c}$ & 0 & 0 & 0 \\
\hline$R+M+P h$ & $94.33 \pm 4.04^{b}$ & $0.11 \pm 0.01^{b}$ & $3.80 \pm 0.31^{b}$ & 17 & 17.52 & 70 \\
\hline
\end{tabular}

The number marked with different superscript letters in the same column show statistic difference at significant level. $\mathrm{R}=$ bradyrhizobium; $\mathrm{Ph}=\mathrm{Phage}$ Control: plant only; $\mathrm{M}=$ mycorrhizae; $\mathrm{F} \%$ = Frequency of root inoculation; $\mathrm{M} \%$ = Intensity of cortical infection; $\mathrm{A} \%$ = Arbuscule frequency in roots. 


\section{$\mathrm{N}, \mathrm{P}$, and $\mathrm{K}$ content}

In cowpea plants inoculated with bradyrhizobium, the presence of phage VB_BrV_SD4 decreased the N percentage in the shoots from 2.47 to 1.45 . However, mycorrhizal inoculation alleviated the presence of phage and improved the reduction from 41.3 to $24.5 \%$ (Table 3). Compared to non-mycorrhized therapies, mycorrhizae increased the $\mathrm{N}$ percentage in seeds.

The $\mathrm{P}$ and $\mathrm{K}$ contents were greatly influenced by mycorrhizae, bradyrhizobium, and rhizobiophage applications (Table 4). On the other hand, the addition
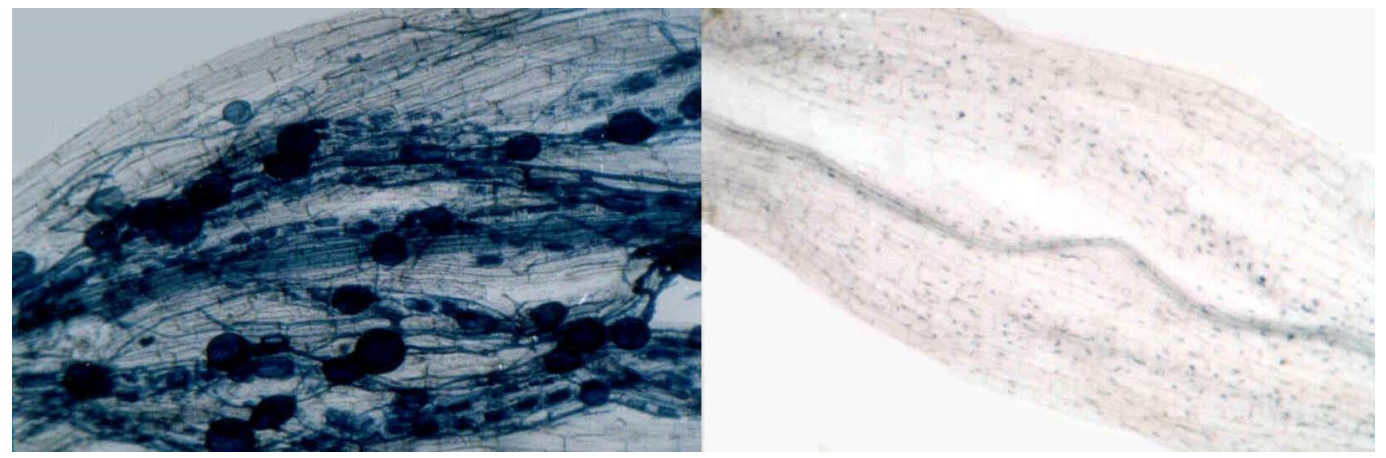

Figure 2 - Non-mycorrhizal segment (right) and mycorrhizal segment (left) of cowpea stained root.

Table 2 - Effect of bradyrhizobial, mycorrhizal, rhizobiophage inoculation in chlorophyll a, chlorophyll b and carotenoids in flowering stage.

\begin{tabular}{lcccc}
\hline Treatment & Total $(\mathrm{a}+\mathrm{b})$ & Carotenoid & Chlorophyll (b) & Chlorophyll (a) \\
\hline Control & $14.26 \pm 0.84^{\mathrm{d}}$ & $6.38 \pm 0.49^{\mathrm{c}}$ & $5.77 \pm 0.29^{\mathrm{d}}$ & $8.49 \pm 0.96^{\mathrm{d}}$ \\
$\mathrm{M}$ & $20.65 \pm 0.37^{\mathrm{ab}}$ & $8.72 \pm 1.01^{\mathrm{a}}$ & $7.87 \pm 0.39^{\mathrm{b}}$ & $12.78 \pm 0.74^{\mathrm{ab}}$ \\
$\mathrm{R}$ & $19.55 \pm 0.30^{\mathrm{b}}$ & $8.68 \pm 1.17^{\mathrm{ab}}$ & $7.82 \pm 0.17^{\mathrm{bc}}$ & $11.73 \pm 0.47^{\mathrm{b}}$ \\
$\mathrm{R}+\mathrm{M}$ & $22.00 \pm 1.46^{\mathrm{a}}$ & $10.00 \pm 1.01^{\mathrm{a}}$ & $8.69 \pm 0.65^{\mathrm{a}}$ & $13.31 \pm 0.88^{\mathrm{a}}$ \\
$\mathrm{R}+\mathrm{Ph}$ & $17.88 \pm 0.40^{\mathrm{c}}$ & $7.08 \pm 0.58^{\mathrm{bc}}$ & $7.17 \pm 0.27^{\mathrm{c}}$ & $10.17 \pm 0.14^{\mathrm{c}}$ \\
$\mathrm{R}+\mathrm{M}+\mathrm{Ph}$ & $20.60 \pm 1.44^{\mathrm{ab}}$ & $9.46 \pm 0.99^{\mathrm{a}}$ & $7.87 \pm 0.42^{\mathrm{b}}$ & $12.73 \pm 1.33^{\mathrm{ab}}$ \\
\hline
\end{tabular}

The number marked with different superscript letters in the same column show statistic difference at significant level. $\mathrm{R}=$ bradyrhizobium; $\mathrm{Ph}=\mathrm{Phage}$ Control: plant only; $\mathrm{M}=$ mycorrhizae.

Table 3 - Effect of bradyrhizobial, mycorrhizal, rhizobiophage inoculation in shoot fresh weight, shoot dry weight, length of shoot, length of root and number of leaves in flowering stage.

\begin{tabular}{|c|c|c|c|c|c|}
\hline Treatment & Shoot fresh weight & Shoot dry weight & Length of shoot & Length of root & Number of leaves \\
\hline & \multicolumn{4}{|c|}{ - g per plant $\longrightarrow$ cm per plant } & $\mathrm{n}$ per plant \\
\hline Control & $18.43 \pm 0.67 \mathrm{e}$ & $3.13 \pm 0.23^{d}$ & $30.00 \pm 2.00^{c}$ & $8.83 \pm 1.04^{e}$ & $19.67 \pm 2.52^{b}$ \\
\hline M & $27.17 \pm 0.15^{b}$ & $5.13 \pm 0.25^{b}$ & $36.53 \pm 1.35^{\mathrm{ab}}$ & $12.67 \pm 1.15^{b c}$ & $26.67 \pm 6.51^{\mathrm{a}}$ \\
\hline $\mathrm{R}$ & $23.70 \pm 1.47^{c}$ & $4.28 \pm 0.38^{c}$ & $33.00 \pm 3.00^{b c}$ & $11.27 \pm 1.25^{\mathrm{cd}}$ & $23.67 \pm 3.51^{\mathrm{ab}}$ \\
\hline$R+M$ & $30.73 \pm 1.60^{a}$ & $5.68 \pm 0.24^{a}$ & $42.43 \pm 6.51^{\mathrm{a}}$ & $15.87 \pm 1.03^{a}$ & $29.67 \pm 3.51^{\mathrm{a}}$ \\
\hline $\mathrm{R}+\mathrm{Ph}$ & $21.90 \pm 0.56^{d}$ & $3.77 \pm 0.42^{c}$ & $30.83 \pm 2.57^{b c}$ & $9.17 \pm 1.61^{d e}$ & $23.00 \pm 3.00^{\mathrm{ab}}$ \\
\hline$R+M+P h$ & $28.73 \pm 0.51^{\mathrm{b}}$ & $5.24 \pm 0.14^{\mathrm{ab}}$ & $41.67 \pm 2.14^{\mathrm{a}}$ & $14.13 \pm 1.03^{\mathrm{ab}}$ & $28.67 \pm 2.52^{\mathrm{a}}$ \\
\hline
\end{tabular}

The number marked with different superscript letters in the same column show Statistic difference at significant level. $\mathrm{R}=$ bradyrhizobium; $\mathrm{Ph}=\mathrm{Phage}$ Control: plant only; $\mathrm{M}=$ mycorrhizae.

Table 4 - Effect of bradyrhizobial, mycorrhizal, rhizobiophage inoculation in nitrogen, phosphorus, potassium in flowering and yield stage.

\begin{tabular}{|c|c|c|c|c|c|c|}
\hline \multirow{2}{*}{ Treatment } & \multicolumn{3}{|c|}{ Shoot system in flowering stage } & \multicolumn{3}{|c|}{ Seeds in yield stage } \\
\hline & $\mathrm{N}$ & $P$ & $\mathrm{~K}$ & $\mathrm{~N}$ & $P$ & $\mathrm{~K}$ \\
\hline & & 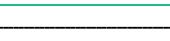 & $\mu g g^{-1}$ & 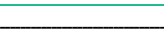 & - & $\mu g^{-1}$ \\
\hline Control & $0.51 \pm 0.18^{c}$ & $0.44 \pm 0.08^{d}$ & $132.00 \pm 9.45^{c}$ & $1.62 \pm 0.78^{e}$ & $0.46 \pm 0.04^{d}$ & $68.67 \pm 3.01^{\circ}$ \\
\hline M & $1.03 \pm 0.61^{c}$ & $3.23 \pm 0.31^{b c}$ & $152.00 \pm 3.64^{b}$ & $3.11 \pm 0.18^{\text {bc }}$ & $3.47 \pm 0.50^{\mathrm{bc}}$ & $84.17 \pm 1.89^{b}$ \\
\hline $\mathrm{R}$ & $2.47 \pm 0.91^{\mathrm{ab}}$ & $2.80 \pm 0.30^{c}$ & $148.66 \pm 4.04^{b}$ & $2.40 \pm 0.62^{\text {cd }}$ & $3.46 \pm 0.50^{\mathrm{bc}}$ & $77.66 \pm 3.01^{\circ}$ \\
\hline$R+M$ & $2.99 \pm 0.65^{a}$ & $4.40 \pm 0.36^{a}$ & $193.00 \pm 11.36^{\mathrm{a}}$ & $4.33 \pm 0.38^{a}$ & $5.04 \pm 0.63^{a}$ & $126.33 \pm 5.13$ \\
\hline $\mathrm{R}+\mathrm{Ph}$ & $1.45 \pm 0.61^{\mathrm{bc}}$ & $2.67 \pm 0.60^{c}$ & $144.33 \pm 5.1^{c}$ & $2.30 \pm 0.49$ de & $3.09 \pm 0.32^{c}$ & $76.50 \pm 4.27$ \\
\hline$R+M+P h$ & $2.26 \pm 0.51^{\mathrm{ab}}$ & $3.75 \pm 0.41^{\mathrm{ab}}$ & $154.67 \pm 5.86^{b}$ & $3.74 \pm 0.59^{a b}$ & $4.19 \pm 0.30^{b}$ & $86.00 \pm 1.32^{\mathrm{b}}$ \\
\hline
\end{tabular}

The number marked with different superscript letters in the same column show statistic difference at significant level. $\mathrm{R}=$ bradyrhizobium; $\mathrm{Ph}=\mathrm{Phage}$ Control: plant only; $\mathrm{M}=$ mycorrhizae. 
of rhizobiophage significantly decreased these contents in the non-mycorrhized cowpea plant. Compared to cowpea plants infected with or without lytic phage, these contents in the dual inoculation of bradyrhizobium and mycorrhizae were significantly higher.

\section{Growth and yield parameters}

Table 4 shows that phage VB_BrV_SD4 reduced all growth measurements of the cowpea plant inoculated with bradyrhizobium from 6.6 to $18.6 \%$. However, mycorrhizal inoculation alleviated the presence of phage and reduced from 1.8 to $11 \%$.

According to Tables 5 and 6 , the presence of phage VB_BrV_SD4 reduced all yield measurements of the cowpea plant inoculated with bradyrhizobium from 12 to $18.8 \%$. However, mycorrhizal inoculation alleviated the presence of phage and reduced from 10 to $4.8 \%$.

\section{Protein content}

Table 6 shows that phage VB_BrV_SD4 reduced the amount of protein in seeds in the cowpea plant inoculated with bradyrhizobium from 187.33 to 147.33 , but mycorrhizal inoculation reduced the presence of phage from 21.4 to $11.8 \%$.

\section{Discussion}

Rhizobiophages influence soil rhizobium (Hashem and Angle, 1990; Liu et al., 2019). However, there is

Table 5 - Effect of bradyrhizobial, mycorrhizal, rhizobiophage inoculation in length of shoot, length of root, length of legume in yield stage.

\begin{tabular}{lcc}
\hline Treatment & Length of legume & Number of seeds \\
\hline Control & cm per legume & $n$ per legume \\
$M$ & $10.83 \pm 0.76^{\mathrm{d}}$ & $6.00 \pm 2.00^{\mathrm{d}}$ \\
$\mathrm{R}$ & $13.83 \pm 0.76^{\mathrm{ab}}$ & $9.67 \pm 0.58^{\mathrm{bc}}$ \\
$\mathrm{R}+\mathrm{M}$ & $12.83 \pm 0.76^{\mathrm{bc}}$ & $8.66 \pm 1.15^{\mathrm{c}}$ \\
$\mathrm{R}+\mathrm{Ph}$ & $15.80 \pm 1.04^{\mathrm{a}}$ & $13.33 \pm 0.58^{\mathrm{a}}$ \\
$\mathrm{R}+\mathrm{M}+\mathrm{Ph}$ & $10.83 \pm 0.76^{\mathrm{d}}$ & $8.00 \pm 1.00^{\mathrm{cd}}$ \\
\hline
\end{tabular}

The number marked with different superscript letters in the same column show statistic difference at significant level. $\mathrm{R}=$ bradyrhizobium; $\mathrm{Ph}=\mathrm{Phage}$ Control: plant only; $\mathrm{M}=$ mycorrhizae. little information about alleviating the negative effect of phages by mycorrhizae, to the best our knowledge. Therefore, this study investigated the reduction of the negative effects of rhizobiophage on the growth and nodulation of the valuable crop Vigna unguiculata.

The isolated phage VB_BrV_SD4, which belongs to the Siphoviridae family, has an icosahedral head with a diameter of $43.44 \mathrm{~nm}$ and a long non-contractile tail, measuring $99.85 \mathrm{~nm}$. Phage VB_BrV_SD4 is similar to phage $\mathrm{Z}$ that has an icosahedral head and a noncontractile tail, according to Jamal et al. (2015). It belongs to the family Siphoviridae of the order Caudovirales.

The results revealed an increase in nodule numbers, nodule dry weight, nitrogenase activity, and plant dry weight of Vigna unguiculata inoculated with bradyrhizobium sp. The presence of phage VB_BrV_ SD4 reduced Vigna (tal16). These findings corroborate results from previous studies (Liu et al., 2019).

Bradyrhizobial inoculation stimulated the nodulation process that affected growth, yield measurements, and chlorophyll and $\mathrm{P}$ contents. These results are in agreement with Arafa et al. (2018) and Verma et al. (2014), who reported that inoculation of cowpea and fenugreek seeds with effective bradyrhizobial strains significantly stimulated yield, total protein yield $\%, \mathrm{~N}$ and $\mathrm{P}$ uptake and total carbohydrate $\%$ in grains and seeds of the two plants.

VAM increased $\mathrm{P}$ absorption, affecting yield, growth, chlorophyll, protein, and $\mathrm{N}$ accumulation in the plant. These findings are consistent with Yaseen et al. (2016). The authors found that mycorrhizal inoculation increased plant yield and chlorophyll content on the leaves of many plants because $\mathrm{P}$ is the primary energy source for plants to absorb $\mathrm{N}$ and develop.

The dual inoculation treatment of VAM and bradyrhizobium in cowpea plants increased growth and yield measurements, chlorophyll, protein, and nodulation process at their maximum value compared to all treatments.

These results are similar to findings of previous studies, which demonstrated that the dual inoculation of seeds with mycorrhizae and bradyrhizobium promoted an increase in all measurements in the cowpea plant due to the increasing photosynthesis process (Moradi et al., 2013; Yaseen et al., 2016), possibly due to the presence

Table 6 - Effect of bradyrhizobial, mycorrhizal, rhizobiophage inoculation in number of seeds, number of legumes, weight of 100 seeds, shoot fresh weight, shoot dry weight and protein in seeds in yield stage.

\begin{tabular}{lcccc}
\hline Treatment & Number of legumes & Weight of 100 seeds & Shoot dry weight & Protein \\
\cline { 2 - 4 } Control & $\mathrm{n}$ per plant & $16.27 \pm 0.54^{\mathrm{f}}$ & $12.33 \pm 0.55^{\mathrm{e}}$ & mg per g fresh weight \\
\cline { 2 - 4 } $\mathrm{M}$ & $16.67 \pm 1.15^{\mathrm{e}}$ & $22.13 \pm 0.67^{\mathrm{c}}$ & $21.60 \pm 0.62^{\mathrm{c}}$ & $211.33 \pm 15.56^{\mathrm{e}}$ \\
$\mathrm{R}$ & $30.67 \pm 2.08^{\mathrm{b}}$ & $20.25 \pm 0.67^{\mathrm{d}}$ & $18.54 \pm 0.57^{\mathrm{d}}$ & $187.33 \pm 10.50^{\text {cd }}$ \\
$\mathrm{R}+\mathrm{M}$ & $26.66 \pm 1.53^{\mathrm{c}}$ & $26.30 \pm 0.49^{\mathrm{a}}$ & $26.71 \pm 0.97^{\mathrm{a}}$ & $270.33 \pm 39.72^{\mathrm{a}}$ \\
$\mathrm{R}+\mathrm{Ph}$ & $36.33 \pm 1.53^{\mathrm{a}}$ & $18.78 \pm 0.51^{\mathrm{e}}$ & $17.37 \pm 0.57^{\mathrm{d}}$ & $147.33 \pm 6.81^{\mathrm{de}}$ \\
$\mathrm{R}+\mathrm{M}+\mathrm{Ph}$ & $21.66 \pm 1.53^{\mathrm{d}}$ & $24.09 \pm 1.22^{\mathrm{b}}$ & $23.63 \pm 1.43^{\mathrm{b}}$ & $238.67 \pm 38.21^{\mathrm{ab}}$ \\
\hline
\end{tabular}

The number marked with different superscript letters in the same column show statistic difference at significant level. $\mathrm{R}=$ bradyrhizobium; $\mathrm{Ph}=\mathrm{Phage}$ Control: plant only; $\mathrm{M}=$ mycorrhizae. 
of a high amount of protein and $\mathrm{P}$ accumulation by bradyrhizobium and mycorrhizae. In the dual inoculation procedure, the mycorrhizal colonization and $\mathrm{P}$ content were at the maximum value. These findings seem to be consistent with other studies that reported a greater effect on nodulation, mycorrhizal colonization, and $\mathrm{P}$ content than mono-inoculation because of the dual inoculation (Stancheva et al., 2006).

The results show that the nutrients absorbed by bradyrhizobium and mycorrhizae to the plants were at a maximum value in the dual inoculation, supporting previous studies (Abdel-Fattah et al., 2016; Abdullahi and Sheriff, 2013; Khalil and Yousef, 2014). The hyphae took the nutrients to plants, leading to efficient mobilization and uptake of $\mathrm{P}, \mathrm{N}$, and $\mathrm{P}$ transported to the plant.

\section{Acknowledgments}

Zagazig and Mansoura University supported the present study from 2017 to 2020 . The authors would like to extend their sincere appreciation to the Researchers Supporting Project Number (RSP-2021/134), King Saud University, Riyadh, Saudi Arabia.

\section{Authors' Contributions}

Conceptualization: El-Didamony, G.; Allam, Y.; Amin, G.; Abdel-Fattah, G. Data acquisition: Egamberdieva, D.; Abd_Allah, E.F. Data analysis: Allam, Y.; Amin, G.; Abdel-Fattah, G. Design of methodology: ElDidamony, G.; Allam, Y.; Amin, G.; Abdel-Fattah, G. Writing and editing: Egamberdieva, D.; Abd_Allah, E.F.; Hashem, A.

\section{References}

Abdel-Fattah, G.; Asrar, A.; Al-Amri, S.; Abdel-Salam, E. 2014. Influence of arbuscular mycorrhiza and phosphorus fertilization on the gas exchange, growth and phosphatase activity of soybean (Glycine max L.) plants. Photosynthetica 52: 581-588.

Abdel-Fattah, G.M.; Shukry, W.M.; Shokr, M.M.; Ahmed, M.A. 2016. Application of mycorrhizal technology for improving yield production of common bean plants. International Journal of Applied Sciences and Biotechnology 4: 191-197.

Abdullahi, R.; Sheriff, H. 2013. Effect of arbuscular mycorrhizal fungi and chemical fertilizer on growth and shoot nutrients content of onion under field condition in northern Sudan Savanna of Nigeria. Journal of Agriculture and Veterinary Science 3: 85-90.

Ackermann, H. -W.; Prangishvili, D. 2012. Prokaryote viruses studied by electron microscopy. Archives of Virology 157: 1843-1849.

Ahmad, M.; Morgan, V. 1994. Characterization of a cowpea (Vigna unguiculata) rhizobiophage and its effect on cowpea nodulation and growth. Biology and Fertility of Soils 18: 297301.
Arafa, M.; El-Batanony, N.; Nofal, A. 2018. Inoculation effect of Bradyrhizobium strains on growth, yield and chemical composition of some legume crops in new reclaimed soil. Middle East Journal of Agriculture Research 7: 352-363.

Artursson, V.; Finlay, R.D.; Jansson, J.K. 2006. Interactions between arbuscular mycorrhizal fungi and bacteria and their potential for stimulating plant growth. Environmental Microbiology 8: 1-10.

Chapman, H.P.E.P. 1961. Methods of analysis for soil, plant and water. Soil Science Journal 93: 67-68.

Dhar, B.; Singh, B.; Singh, R.; Srivastava, J.; Singh, V.; Singh, R. 1979. Occurrence and distribution of rhizobiophages in Indian soils. Acta Microbiologica Polonica 28: 319-324.

Gerdemann, J.; Nicolson, T.H. 1963. Spores of mycorrhizal Endogone species extracted from soil by wet sieving and decanting. Transactions of the British Mycological Society 46: 235-244.

Hardy, R.; Burns, R.C.; Holsten, R.D. 1973. Applications of the acetylene-ethylene assay for measurement of nitrogen fixation. Soil Biology and Biochemistry 5: 47-81.

Hartee, E. 1972. Determination of protein: a modification of the Lowry method that gives a linear photometric response. Analytical Biochemistry 48: 422-427.

Hashem, F.; Angle, J. 1990. Rhizobiophage effects on nodulation, nitrogen fixation, and yield of field-grown soybeans (Glycine max L. Merr.). Biology and Fertility of Soils 9: 330-334.

Heffner, E.L.; Sorrells, M.E.; Jannink, J.L. 2009. Genomic selection for crop improvement. Crop Science 49: 1-12.

Horváth, G.; Kissimon, J.; Faludi-Daniel, A. 1972. Effect of light intensity on the formation of carotenoids in normal and mutant maize leaves. Phytochemistry 11: 183-187.

Huang, P.; de-Bashan, L.; Crocker, T.; Kloepper, J.W.; Bashan, Y. 2017. Evidence that fresh weight measurement is imprecise for reporting the effect of plant growth-promoting (rhizo) bacteria on growth promotion of crop plants. Biology and Fertility of Soils 53: 199-208.

Jamal, M.; Hussain, T.; Das, C.R.; Andleeb, S. 2015. Characterization of Siphoviridae phage $\mathrm{Z}$ and studying its efficacy against multidrug-resistant Klebsiella pneumoniae planktonic cells and biofilm. Journal of Medical Microbiology 64: 454-462.

Jackson, N.E. 1973. Soil Chemical Analysis. Prentice Hall, Englewood Cliffs, NJ, USA.

Khalil, S.E.; Yousef, R.M. 2014. Interaction effects of different soil moisture levels, arbuscular mycorrhizal fungi and thee phosphate levels on. I. Growth, yield and photosynthetic activity of garden cress (Lepidium sativum L.) plant. International Journal of Advanced Research 2: 723-737.

Levesque, R. 2007. SPSS Programming and Data Management: A Guide for SPSS and SAS Users. SPSS, Armonk, NY, USA.

Liu, J.J.; Liu, Z.X.; Yu, H.; Yao, Q.; Yu, Z.H.; Wang, G.H. 2019. Biological characteristics of bacteriophages infecting thee typic rhizobia of legume. The Journal of Applied Ecology 30: 2775-2782.

Metzner, H.; Rau, H.; Senger, H. 1965. Untersuchungen zur synchonisierbarkeit einzelner pigmentmangel-mutanten von Chlorella. Planta 65: 186-194. 
Moradi, S.; Sheikhi, J.; Zarei, M. 2013. Effects of arbuscular mycorrhizal fungi and Rhizobium on shoot and root growth of chickpea in a calcareous soil. International Journal of Agriculture 3: 381.

Mugabo, J.P.; Bhople, B.S. 2015. Effect of Arbuscular Mycorrhizal Fungi and Rhizobium Inoculation on Root Morphology and Chemical Properties of Rhizospheric Soils in Field Pea (Pisum Sativum L.). Lovely Professional University, Punjab, India.

Muleta, D. 2017. Legume response to arbuscular Mycorrhizal fungi inoculation in sustainable agriculture. p. 227-260. In: Zaidi, A.; Khan, M.S.; Musarrat, J., eds. Microbes for Legume Improvement. Springer, Berlin, Germany.

Nelson, D.W.; Sommers, L.E. 1973. Determination of total nitrogen in plant material. Agronomy Journal 65: 109-112.

Phillips, J.M.; Hayman, D. 1970. Improved procedures for clearing roots and staining parasitic and vesiculararbuscular mycorrhizal fungi for rapid assessment of infection. Transactions of the British Mycological Society 55: 158-161.

Rai, M. 2006. Handbook of Microbial Biofertilizers: CRC Press, Boca Raton, FL, USA.

Singh, A.K.; Tripathi, P.; Singh, R. 2007. Effect of Rhizobium inoculation, nitrogen and phosphorus levels on growth, yield and quality of kharif cowpea [Vigna unguiculata (L.) Walp.]. Crop Research-Hisar 33: 71.

Stancheva, I.; Geneva, M.; Zehirov, G.; Tsvetkova, G.; Histozkova, M.; Georgiev, G. 2006. Effects of combined inoculation of pea plants with arbuscular mycorrhizal fungi and Rhizobium on nodule formation and nitrogen fixing activity. General and Applied Plant Physiology 32: 61-66 special issue.
Swanson, M.; Fraser, G.; Daniell, T.; Torrance, L.; Gregory, P.; Taliansky, M. 2009. Viruses in soils: morphological diversity and abundance in the rhizosphere. Annals of Applied Biology 155: 51-60.

Van der Heijden, M.G.A.; Martin, F.M.; Selosse, M.A.; Sanders, I.R. 2015. Mycorrhizal ecology and evolution: the past, the present, and the future. New Phytologist 205: 1406-1423.

Verma, P.; Yadav, A.N.; Kazy, S.K.; Saxena, A K.; Suman, A. 2014. Evaluating the diversity and phylogeny of plant growth promoting bacteria associated with wheat (Triticum aestivum) growing in central zone of India. International Journal of Current Microbiology and Applied Sciences 3: 432-447.

Whiting, M.; Dilworth, M. 1974 Legume root nodule nitrogenase: purification, properties, and studies on its genetic control. Biochimica et Biophysica Acta. Protein Structure 371: 337-351.

Yaseen, T.; Ali, K., Munsif, F.; Rab, A.; Ahmad, M.; Israr, M.; Baraich, K. 2016 Influence of arbuscular mycorrhizal fungi, Rhizobium inoculation and rock phosphate on growth and quality of lentil. Pakistan Journal of Botany 48: 2101-2107.

Zhu, H.; Yao, Q. 2004. Localized and systemic increase of phenols in tomato roots induced by Glomus versiforme inhibits Ralstonia solanacearum. Journal of Phytopathology 152: 537-542. 